\title{
Pengaruh ZIS, Pertumbuhan Ekonomi, Pengangguran dan Inflasi Terhadap Tingkat Kemiskinan di Indonesia
}

\section{The Effect Of Zis, Economic Growth, Unemployment And Inflation On Poverty Levels In Indonesia}

\author{
Ayu Sindi Widiastuti ${ }^{1 *}$, Kosasih ${ }^{2}$ \\ ${ }^{12}$ Prodi Akuntansi, Fakultas Ekonomi dan Bisnis, Universitas Singaperbangsa Karawang \\ Jl. HS. Ronggo Waluyo, Telukjambe Timur, Karawang, Jawa Barat, 41361, Indonesia \\ ${ }^{*}$ E-mail: ayusindi29@gmail.com
}

Naskah masuk:2021-03-30

Naskah diperbaiki:2021-04-02

Naskah diterima: 2021-04-06

ABSTRAK

Kemiskinan menjadi masalah yang serius dan sangat penting di setiap negara termasuk Indonesia. Dengan demikian penanggulangan kemiskinan merupakan kebijakan yang harus selalu diterapkan dengan mengimpelementasikan langkah-langkah konkrit dalam pelaksanaanya. Berdasarkan teori teori yang ada dan penelitian terdahulu yang telah dilakukan, banyak sekali faktor yang dapat mempengaruhi tingkat kemiskinan diantaranya adalah jumlah penduduk, pendapatan perkapita, ketebatasan sumber daya, kurangnya tingkat pendidikan, sedikitnya lapangan pekerjaan dan sebagainya. Penelitian ini bertujuan untuk menguji beberapa faktor mempengaruhi tingkat kemiskinan diantaranya adalah ZIS, pertumbuhan ekonomi, pengangguran dan inflasi. Penelitian ini menggunakan pendekatan kuantitatif dan data yang digunakan adalah data sekunder dari tahun 2010 hingga 2019 yang diambil dari BPS dan Baznas. Pengolahan datanya menggunakan analisis regresi linear berganda dan uji hipotesis menggunakan Sofware SPSS 16. Hasil penelitian menunjukkan bahwa variabel ZIS tidak berpengaruh signifikan dengan nilai probabilitas 0,052 dan berarah negatif dengan nilai koefisien -2.537 sedangkan variabel pertumbuhan ekonomi dan inflasi tidak berpengaruh signifikan terhadap tingkat kemiskinan dengan nilai probabilitas 0,016 dan 0,523. Kemudian variabel pengangguran berpengaruh signifikan dengan nilai probabilitas 0,006 dan berarah positif dengan nilai koefisien 4.526. Hasil yang didapat dari Uji R2 dalam penelitian ini menunjukkan bahwa tingkat kemiskinan di Indonesia dapat dijelaskan oleh variabel ZIS, Pertumbuhan ekonomi, pengangguran dan inflasi sebesar 95,7\% dan sisanya dijelaskan oleh variabel lain diluar variabel yang diteliti dalam penelitian ini.

Kata kunci: inflasi, kemiskinan, pengangguran, ZIS

\section{ABSTRACT}

Poverty is a serious and very important problem in every country, including Indonesia. Thus poverty alleviation is a policy that must always be implemented by implementing concrete steps in its implementation. Based on existing theories and previous research that has been carried out, there are many factors that can affect the level of poverty including population, per capita income, limited resources, lack of education level, lack of employment opportunities and so on. This study aims to examine several factors affecting poverty levels including ZIS, economic growth, unemployment and inflation. This research uses a quantitative approach and the data used is secondary data from 2010 to 2019 taken from BPS and Baznas. The data processing used multiple linear regression analysis and hypothesis testing using SPSS 16 software. The results showed that the ZIS variable did not have a significant effect with a probability value of 0.052 and a negative direction with a coefficient value of 2.537 while the variables of economic growth and inflation had no significant effect on the poverty level. probability 0.016 and 0.523 . Then the unemployment variable has a significant effect with a probability value of 0.006 and has a positive direction with a coefficient value of 4.526 . The results obtained from the R2 test in this study indicate that the poverty rate in Indonesia can be explained by the ZIS variable, 
economic growth, unemployment and inflation by $95.7 \%$ and the rest is explained by other variables outside the variables examined in this study.

Keywords: inflation, poverty, unemployment, ZIS

Copyright (C) 2021 Program Studi Ekonomi Perbankan Islam, FEB Universitas Majalengka. All rights reserved.

\section{PENDAHULUAN}

Kemiskinan merupakan isu global maupun nasional yang masih menjadi perhatian besar bagi banyak pihak. Dalam hal ini, sebagai negara Indonesia masih dihinggapi masalah kemiskinan dimana sebanyak 25,14 juta orang $(9,14 \%)$ penduduk miskin yang tercatat pada Maret 2019. Adanya keterbelakangan dan pengangguran menandai terjadinya kemiskinan, karena Indonesia merupakan negara yang sangat luas wilayahnya dan memiliki kondisi soal budaya masyarakat yang beragam. Kondisi kemiskinan yang berbeda memicu terjadinya ketimpangan pendapatan dan kesenjangan antar kelompok di masyarakat sehingga sulit untuk mengentaskan kemiskinan. Berikut data penduduk miskin tahun 2010-2019 :

Tabel 1.

Penduduk Miskin Tahun 2010-2019

\begin{tabular}{|c|c|c|}
\hline Tahun & $\begin{array}{c}\text { Penduduk Miskin } \\
\text { (dalam jutaan) }\end{array}$ & $\begin{array}{c}\text { Tingkat Penduduk } \\
\text { Miskin (\%) }\end{array}$ \\
\hline 2010 & 31,02 & 13,33 \\
\hline 2011 & 30,12 & 12,49 \\
\hline 2012 & 29,25 & 11,96 \\
\hline 2013 & 28,17 & 11,36 \\
\hline 2014 & 28,28 & 11,25 \\
\hline 2015 & 28,59 & 11,22 \\
\hline 2016 & 28,01 & 10,86 \\
\hline 2017 & 27,77 & 10,64 \\
\hline 2018 & 25,95 & 9,82 \\
\hline 2019 & 25,14 & 9,41 \\
\hline
\end{tabular}

Sumber : BPS, Angka Maret (data diolah, 2021)

Dapat dilihat dari Tabel 1. diatas bahwa tingkat penduduk miskin selama sepuluh tahun terakhir terus menurun. Sebanyak 31,02 juta jiwa penduduk miskin tercatat di tahun 2010 dan terus mengalami penurunan. Meskipun di tahun 2015 mengalami kenaikan sebanyak 0,31 juta jiwa, namun ditahun 2016 tingkat kemiskinan kembali turun 0,36 persen. Secara absolut jumlah penduduk miskin turun sebesar 0,58 juta jiwa terhitung dari Maret 2015 - Maret 2016. Derdasarkan data yang dipublikasikan oleh BPS tingkat kemiskinan di Indonesia mencapai titik terendah terjadi di 2019 yaitu sebesar 9,41 persen. Dilihat dari angka-angka diatas mengindikasikan bahwa program-program yang dilakukan pemerintah untuk mengatasi masalah kemiskinan belum berhasil.

Dalam menanggulangi kemiskinan sudah dilakukan berbagai upaya diantaranya dengan menyediakan kebutuhan dasar, pelatihan kerja, pelayanan kesehatan masyarakat, pendidikan, dan sebagainya. Islam telah memberikan berbagai solusi dalam mengentaskan kemiskinan, diantaranya adalah dengan anjuran untuk bekerja bagi umat muslim, redistribusi pendapatan berupa ZIS (Zakat, Infaq, Shadaqah) dan lainnya. Dalam perspektif ekonomi Islam salah satu upaya mengatasi kemiskinan adalah dengan ZIS (Zakat, Infaq, Shadaqah). Salah satu instrumen fiskal dalam 
ekonomi islam adalah zakat yang sangat strategis berpengaruh terhadap perekonomian. Dalam Islam, setiap muslim diwajibkan untuk mengeluarkan zakat, karena dapat membersihkan jiwa dengan tujuan untuk memperoleh berkah, menunaikan kewajiban serta dapat memberikan berbagai kebaikan.
Zakat yang dihimpun, dikelola dan didistribusikan dengan baik dan tepat akan mampu memberikan potensi yang cukup besar untuk mendorong turunnya tingkat kemiskinan. Zakat ini berfungsi mendorong seseorang mengeluarkan hartanya untuk dimanfaatkan secara produktif. Berikut data penghimpunan ZIS pada tahun 2010-2019:

Tabel 2.

Penghimpunan ZIS

\begin{tabular}{|c|c|}
\hline Tahun & Penghimpunan \\
\hline 2010 & 1.500 .164 .240 .975 \\
\hline 2011 & 1.728 .864 .359 .398 \\
\hline 2012 & 2.212 .398 .951 .344 \\
\hline 2013 & 2.639 .604 .069 .729 \\
\hline 2014 & 3.300 .000 .000 .000 \\
\hline 2015 & 3.650 .369 .012 .964 \\
\hline 2016 & 5.017 .293 .126 .950 \\
\hline 2017 & 6.224 .371 .269 .471 \\
\hline 2018 & 8.117 .597 .683 .267 \\
\hline 2019 & 10.227 .943 .806 .555 \\
\hline
\end{tabular}

Sumber : BAZNAS (data diolah, 2021)

Berdasarkan Tabel 2. terlihat bahwa penghimpunan dana ZIS sertiap tahunnya terus menerus mengalami peningkatan. Hal ini menunjukkan bahwa pengumpulan zakat sudah optimal sehingga dapat mengurangi angka kemiskinan dan mendorong peningkatan tumbuhnya ekonomi Indonesia. Pertumbuhan ekonomi dikatakan dapat mempengaruhi tingkat kemiskinan. Keberhasilan perekonomian suatu negara dapat dilihat dari aktifitas perkembangan ekonomi, kesejahteraan masyarakat dapat terjadi apabila pertumbuhan ekonomi meningkat yang berdampak pada peningkatan pendapatan di masyarakat. (Nurotul, 2020). Maka dengan meningkatnya pertumbuhan ekonomi dan pemerataan pendapatan berdampak pada laju penurunan penduduk miskin.

Tingkat kemiskinan juga dapat dipengaruhi oleh indikator lain yaitu pengangguran. Di negara-negara berkembang mengurangi pengangguran merupakan prioritas penting bagi pemerintah sebagai upaya mengatasi kemiskinan di suatu negara. Menurut teori, apabila masyarakat bekerja kemudian mendapatkan penghasilan yang digunakan untuk memenuhi kebutuhan pokoknya maka dapat dikatakan tidak ada masyarakat miskin. Dengan demikian apabila turunnya tingkat pengangguran maka akan menyebabkan turunnya tingkat kemiskinan. (Alifia, 2020).

Indikator lain yang mempengaruhi kemiskinan antara lain adalah inflasi. Inflasi yang fluktuatif dan tinggi merupakan cerminan dari ketidakstabilan perekonomian yang berdampak terjadinya peningkatan harga barang ataupun jasa yang bergerak secara kontinu sehingga dapat mempengaruhi tingkat kemiskinan. Pemerintah dalam mengendalikan inflasi telah melalukan berbagai upaya dengan mengeluarkan berbagai kebijakan fiskal maupun kebijakan moneter. Dengan harapkan kebijakan tersebut dapat 
menstabilkan kenaikan inflasi agar harga barang dan jasa tidak melambung tinggi sehingga daya beli masyarakat meningkat dan adanya pemerataan pendapatan yang akhirnya dapat mempengaruhi tingkat kemiskinan. Berdasarkan kondisi yang terjadi maka penulis akan meneliti mengenai pengaruh dari ZIS, pengangguran, pertumbuhan ekonomi dan inflasi terhadap tingkat kemiskinan tahun 2010-2019. Dengan harapan penelitian ini menjadi bahan referensi bagi pemerintah membuat kebijakan fiskal agar lebih fokus dan konsisten dalam upaya untuk mengetaskan kemiskinan dan pemerataan ekonomi sehingga tidak terjadi ketimpangan.

\section{METODE}

Penelitian ini menggunakan metode pendekatan kuantitatif, yaitu pendekatan yang lebih indentik dengan angka. Pendekatan kuantitatif mengutamakan pengujian hipotesis yang mengarah kepada berbagai pembuktian, agar fenomena yang dijelaskan lebih terukur dengan hasil generalisasi. Biasanya dalam pendekatan ini suatu masalah diarahkan menjadi hubungan kausalitas sehingga pada pelaksanaannya dapat menjelaskan rumusan masalah dengan berbagai variabel. Metode analisis yang digunakan adalah metode uji regresi berganda dan uji hipotesis. Jenis data yang digunakan adalah sekunder yaitu data time series. Peneliti mengumpulkan data yang bersumber dari situs resmi instansi pemerintah yang telah dipublikasikan seperti BPS dan BAZNAS untuk kemudian dipelajari dan dilakukan pengolahan data.

\section{Populasi dan Sampel}

ZIS, Pertumbuhan Ekonomi, Pengangguran, Inflasi, dan Tingkat Kemiskinan merupakan populasi yang digunakan pada penelitian ini dengan kurun waktu sepuluh tahun, yaitu tahun 2010-2019. Kemudian penelitian ini menggunakan teknik sampling jenuh, yaitu teknik penetapan sampel jika semua anggota populasi digunakan dalam sampel (Sujarweni, 2016).

\section{Variabel Independen}

\section{Zakat, Infaq dan Shadaqah (ZIS)}

Menurut Peraturan Menteri Agama Nomor 52 Tahun 2014 adalah kewajiban untuk mengerluarkan hartanya bagi seseorang atau badan usaha yang beragama islam untuk didistribusikan kepada pihak yang membutuhkan atau yang berhak menerima zakat berdasarkan syariat islam yang telah ditetapkan. Sedangkan Infaq dan sedekah merupakan harta yang dapat keluarkan kapan saja oleh seorang muslim dan tidak memiliki batasan seberapa banyak jumlahnya atau disebut juga nishab (Rumah zakat, 2019).

\section{Pertumbuhan Ekonomi}

Dalam terma ekonomi modern dijelaskan pertumbuhan ekonomi merupakan peningkatan kemakmuran masyarakat yang diakibatkan oleh meningkatnya produksi barang ataupun jasa di masyarakat mengalami laju perkembangan pendapatan. Produk nasional bruto dan produk domestik bruto digunakan sebagai alat ukur untuk melihat tingkat pertumbuhan ekonomi berdasarkan pendapatan nasional riil yang dicapai suatu negara.

\section{Pengangguran}

Pengangguran ialah angkatan kerja tetapi belum bekerja atau belum mendapatkan pekerjaan yang tetap. Pengangguran biasanya diakibatkan karena masih sedikitnya lowongan kerja yang disediakan tidak sebanding dengan banyaknya angkatan kerja.

Inflasi

Inflasi adalah rata-rata kenaikan tingkat harga dan berlangsung secara kontinu. Inflasi disebabkan oleh berbagai faktor yang berkaitan dengan mekanisme pasar, diantaranya adalah adanya ketidaklancaran distribusi barang dan tingginya konsumsi masyarakat .

\section{Variabel dependen \\ Kemiskinan}

Kemiskinan dapat didefinisikan sebagai kondisi dimana seseorang atau sekelompok 
orang yang tidak mampu memenuhi kebutuhan dasarnya serta tidak memiliki hak dasar kehidupan yang layak dan bermartabat.

\section{HASIL DAN PEMBAHASAN}

Penelitian ini menggunakan metode analisis regresi linear berganda untuk mengetahui pengaruh ZIS, Pertumbuhan Ekonomi, Pengangguran dan Inflasi terhadap tingkat kemiskinan yang terjadi di Indonesia pada tahun 2010-2019, berdasarkan data yang didapatkan dan diolah menggunakan software Spss 16 memberikan hasil penelitian adalah sebagai berikut:

\section{Statistik Deskriptif}

Digunakan untuk melihat deskripsi tentang karakteristik variabel penelitian yang di uji berupa nilai minimal, nilai maksimal, nilai mean, dan simpangan baku. Hasil uji statistik deskriptif dapat dilihat dari tabel dibawah ini adalah sebagai berikut:

Tabel 3.

Hasil Statistik Deskriptif

\begin{tabular}{|l|l|l|l|l|l|}
\hline & $\mathrm{N}$ & Min & Max & Mean & Std. Dev \\
\hline ZIS & 10 & $3 . \mathrm{E} 10$ & $3 . \mathrm{E} 11$ & $1.04 \mathrm{E} 11$ & $8.542 \mathrm{E} 10$ \\
GDP & 10 & 4.79 & 6.50 & 5.4710 & .61846 \\
Pengangguran & 10 & 5.23 & 7.14 & 5.9760 & .59388 \\
Inflasi & 10 & 2.72 & 8.38 & 4.7620 & 2.24137 \\
Kemiskinan & 10 & 9.41 & 13.33 & 11.2350 & 1.17075 \\
Valid N & 10 & & & & \\
\hline
\end{tabular}

Sumber: Hasil SPSS 16, diolah peneliti, 2021

Dilihat dari tabel 3. diatas diketahui bahwa jumlah data yang digunakan yaitu sebanyak 10 data. Pada variabel ZIS terlihat bahwa nilai minimum adalah 3.E10 dan nilai maximum adalah 3.E11. Nilai mean dari variabel ZIS adalah 1.04E11 dengan standar deviasi sebesar 8.542E10. Pada variabel pertumbuhan ekonomi (GDP) terlihat bahwa nilai minimum adalah 4.79 yang terdapat di tahun 2015 dan nilai maximum adalah 6.50 yang terdapat di tahun 2011. Nilai mean dari variabel pertumbuhan ekonomi (GDP) adalah 5.4710 dengan standar deviasi adalah 0.61846 .

Pada variabel pengangguran terlihat bahwa nilai minimum adalah 5.23 yang terdapat di tahun 2019 dan nilai maximum adalah 7.14 yang terdapat di tahun 2010 . Nilai mean dari variabel pengangguran adalah 5.9760 dengan standar deviasi sebesar 0.59388. kemudian, pada variabel inflasi terlihat bahwa nilai minimum adalah 2.72 yang terdapat di tahun 2019 dan nilai maximum adalah 8.38 yang terdapat di tahun 2013. Nilai mean dari inflasi adalah 4.7620 dengan nilai standar deviasi sebesar 2.24137 .

\section{Uji Asumsi Klasik}

\section{a. Uji Normalitas}

Pada uji normalitas Kolmogorov-Smirnov (K-S) apabila nilai signifikansi lebih dari 5\% atau 0,05 maka data beristribusi normal. Berikut adalah hasil uji normalitas pada penelitian ini: 
Tabel 4. Uji Normalitas

One-Sample Kolmogorov-Smirnov Test

\begin{tabular}{|c|c|c|}
\hline & & Unstd. Residual \\
\hline \multicolumn{2}{|l|}{$N$} & 10 \\
\hline \multirow[t]{2}{*}{ Normal Parameters ${ }^{a}$} & Mean & .0000000 \\
\hline & Std. Deviation & .18150339 \\
\hline \multirow[t]{3}{*}{ Most Extreme Differences } & Absolute & .198 \\
\hline & Positive & .110 \\
\hline & Negative & -.198 \\
\hline Kolmogorov-Smirnov Z & & .627 \\
\hline Asymp. Sig. (2-tailed) & & .827 \\
\hline
\end{tabular}

Sumber: SPSS 16, data diolah peneliti, 2021

Hasil uji normalitas dapat dilihat dari tabel 4. menunjukkan nilai dari Asymp.Sig yaitu 0.827. Sehingga nilai signifikansi yang diperoleh adalah 0.827 nilai tersebut lebih besar dari nilai signifikansi yang ditetapkan yaitu $0,05(0.827>0,05)$ maka dapat ditarik kesimpulan bahwa data berdistribusi normal dalam penelitian ini.

\section{b. Uji Multikolinieritas}

Uji multikolinieritas bertujuan untuk menguji korelasi yang terjadi antarvariabel independen (bebas) pada model regresi. Dikatakan tidak terjadi multikoliniertas jika nilai Tolerance $\leq 0,10$ atau sama dengan nilai VIF $\geq 10$. Berikut adalah hasil uji multikolinieritas pada penelitian ini:

Tabel 5. Uji Multikolinieritas

Coefficients $^{\mathrm{a}}$

\begin{tabular}{|ll|l|l|}
\hline \multicolumn{3}{|c|}{ Collinearity Statistics } \\
\cline { 3 - 4 } Model & & Tolerance & VIF \\
\hline 1 & ZIS & .325 & 3.074 \\
& GDP & .512 & 1.953 \\
& Pengangguran & .242 & 4.131 \\
& Inflasi & .690 & 1.450 \\
\hline
\end{tabular}

Sumber: Hasil SPSS 16, diolah peneliti, 2021

Hasil pengujian uji multikolinieritas dapat dilihat dari tabel 5 . dengan nilai tolerance untuk variabel ZIS adalah 0,325, variabel GDP adalah 0,512, variabel pengangguran adalah 0,242 dan variabel inflasi adalah 0.690 . Sedangkan nilai VIF untuk variabel ZIS adalah 3,074 , variabel GDP adalah 1,953 , variabel pengangguran adalah 4,131 dan variabel inflasi adalah 1,450. Sesuai dengan kriteria yang telah ditetapkan maka tidak terdapat variabel independen yang memiliki nilai tolerance kurang dari 0,01 dan nilai VIF yang lebih dari 10. Dapat dikatakan bahwa dalam penelitian ini tidak ada gejala multikolinieritas antarvariabel independen.

\section{c. Uji Heterokedastisitas}

Uji heterokedastisitas yang digunakan pada penelitian ini adalah uji glejser. Dibawah ini adalah hasil dari uji heterokedastisitas sebagai berikut: 
Tabel 6. Uji Heterokedastisitas Coefficients $^{\mathrm{a}}$

\begin{tabular}{|c|c|c|c|c|c|}
\hline \multirow[b]{2}{*}{ Model } & \multicolumn{2}{|c|}{ Unstd. Coefficients } & \multirow{2}{*}{\begin{tabular}{|l} 
Std. \\
Coefficients \\
Beta \\
\end{tabular}} & \multirow[b]{2}{*}{$\mathrm{t}$} & \multirow[b]{2}{*}{ Sig. } \\
\hline & B & Std. Error & & & \\
\hline 1 (Constant) & .076 & .577 & & .132 & .900 \\
\hline ZIS & 7.136E-14 & .000 & .065 & .114 & .914 \\
\hline GDP & -.089 & .069 & -.583 & -1.288 & .254 \\
\hline Pengangguran & .075 & .104 & .476 & .723 & .502 \\
\hline Inflasi & .021 & .016 & .490 & 1.257 & .264 \\
\hline
\end{tabular}

Sumber: Hasil SPSS 16, data diolah peneliti, 2021

Dari tabel 6. diatas dapat dilihat hasil uji heterokedatisitas yaitu nilai sig. variabel ZIS adalah $0,914(0,914>0,05)$, nilai sig. variabel $\operatorname{GDP}$ adalah $0,254(0,254>0,05)$, nilai sig. variabel pengangguran adalah $0,502(0,502>0,05)$ dan nilai sig. variabel inflasi adalah 0,264 $(0,264>0,05)$. Dari hasil Uji Glejser yang telah dilakukan nilai propabilitas seluruh variabel tidak ada yang lebih 0,05. Maka kesimpulan yang ditarik yaitu tidak terdapat masalah heterokedastisitas.

\section{d. Uji Autokorelasi}

Uji Run Test adalah uji autokorelasi yang digunakan dalam penelitian ini. Untuk menentukan terjadi atau tidak terjadinya autokorelasi dapat dilihat dari Jika nilai probabilitas signifikani lebih besar dari $\alpha=0,05$. Dalam suatu penelitian uji ini digunakan untuk melihat kemungkinan munculnya kesalahan variabel pengganggu pada suatu periode.

Tabel 7. Uji Autokorelasi Uji Run Test

\begin{tabular}{|l|l|}
\hline & \multicolumn{1}{|c|}{ Unstd. Residual } \\
\hline Test Value $^{\mathrm{a}}$ & .04940 \\
Cases $<$ Test Value & 5 \\
Cases $>=$ Test Value & 5 \\
Total Cases & 10 \\
Number of Runs & 6 \\
Z & .000 \\
Asymp. Sig. (2-tailed) & 1.000 \\
\hline
\end{tabular}

Sumber: SPSS 16, data diolah peneliti, 2021

Berdasarkan tabel 7. hasil uji Run Test terlihat bahwa nilai Asymp. Sig. (2-tailed) sebesar 1,000 dan yang berarti lebih besar daripada $0,05(1,000>0,05)$, maka dapat disimpulkan bahwa tidak ada gejala autokorelasi antarresidual. 


\section{Analisis Regresi Linear Berganda}

Pengujian regresi linear berganda digunakan untuk menguji pengaruh dan memperlihatkan nilai dari $\left(\mathrm{X}_{1}\right),\left(\mathrm{X}_{2}\right),\left(\mathrm{X}_{3}\right)$ dan $\left(\mathrm{X}_{4}\right)$ terhadap $(\mathrm{Y})$.

\section{Tabel 8. Analisis Regresi Linear Berganda}

\section{Coefficiens}

\begin{tabular}{|c|c|c|c|c|c|}
\hline \multirow[b]{2}{*}{ Model } & \multicolumn{2}{|c|}{ Unstd. Coefficients } & \multirow{2}{*}{$\begin{array}{l}\text { Stand. } \\
\text { Coefficients } \\
\text { Beta }\end{array}$} & \multirow[b]{2}{*}{$t$} & \multirow[b]{2}{*}{ Sig. } \\
\hline & B & Std. Error & & & \\
\hline 1 (Constant) & 2.691 & 1.538 & & 1.750 & .141 \\
\hline ZIS & $-4.227 \mathrm{E}-12$ & .000 & -.308 & -2.537 & .052 \\
\hline GDP & .295 & .183 & .156 & 1.607 & .169 \\
\hline Pengangguran & 1.257 & .278 & .638 & 4.526 & .006 \\
\hline Inflasi & -.030 & .044 & -.057 & -.687 & .523 \\
\hline
\end{tabular}

Sumber: Hasil SPSS 16, data diolah, 2021

Berdasarkan Tabel 8. diatas dengan melihat nilai koefisien dan nilai konstanta, maka dapat disusun persamaan regresi, yaitu:

\section{Kemiskinan $=2,691-4,227$ ZIS + 0,295 GDP $+1,257$ Pengangguran $-0,030$ Inflasi}

Hasil pengujian regresi linear berganda dapat dilihat dari tabel 8. diatas dan akan diuraikan sebagai berikut:

a. Nilai konstanta $(\alpha)$ adalah 2,692, yang berarti jika variabel ZIS, GDP, Pengangguran dan Inflasi nilainya 0, maka tingkat kemiskinan adalah 2,691.

b. Nilai koefisien regresi variabel ZIS ( $\beta 1)$ memiliki nilai negatif yaitu $-4,227$, maka dapat dikatakan jika setiap variabel ZIS mengalami peningkatan sebesar $1 \%$ maka akan menurunkan tingkat kemiskinan sebesar -4,227 dengan anggapan nilai variabel independen yang lain nilainya konstan.

c. Nilai koefisien regresi variabel GDP (B2) memiliki nilai positif yaitu 0,295 , maka dapat dikatakan jika setiap variabel Pertumbuhan Ekonomi (GDP) mengalami peningkatan sebesar $1 \%$ maka tingkat kemiskinan akan naik sebesar 0,295 dengan anggapan nilai variabel independen yang lain nilainya konstan.

d. Nilai koefisien regresi variabel Pengangguran ( $\beta 3$ ) memiliki nilai positif yaitu 1,257, maka dapat dikatakan jika variabel Pengangguran mengalami peningkatan sebesar $1 \%$ maka tingkat kemiskinan akan naik sebesar 1,257 dengan anggapan nilai variabel independen yang lain nilainya konstan.

e. Nilai koefisien regresi variabel Inflasi (B4) memiliki nilai negatif yaitu $-0,030$, maka dapat dikatakan jika setiap variabel Inflasi mengalami peningkatan sebesar $1 \%$ maka akan menurunkan tingkat kemiskinan sebesar -0,030 dengan anggapan nilai variabel independen yang lain nilainya konstan.

\section{Pengujian Koefisien Determinasi $\left(\mathbf{R}^{2}\right)$}

Koefisien determinasi $\left(R^{2}\right)$ bertujuan menjabarkan besarnya pengaruh dari seluruh variabel bebas terhadap variabel terikat. Hasil pengujian koefisien determinasi $\left(R^{2}\right)$ yang diperoleh yaitu:

\section{Tabel 9. Uji R Square \\ Model Summary}




\begin{tabular}{|l|l|l|l|l|}
\hline Model & $R$ & R Square & $\begin{array}{l}\text { Adjusted } \\
\text { Square }\end{array}$ & $\begin{array}{l}\text { Std. Error of the } \\
\text { Estimate }\end{array}$ \\
\hline 1 & $.988^{\mathrm{a}}$ & .976 & .957 & .24351 \\
\hline
\end{tabular}

Sumber: Hasil SPSS 16, data diolah peneliti, 2021

Dari perhitungan tabel 9. nilai koefisien determinasi (adjusted $R 2$ ) adalah 0,957 yang artinya nilai tersebut memperlihatkan bahwa variabel dependen dipengaruhi oleh variabel independen sebesar 95,7 persen, sedangkan sisanya sebesar 4,3 persen disebabkan oleh variabel lain.

\section{Uji t (parsial)}

Dalam suatu penelitian, uji $t$ memiliki bertujuan untuk melihat pengaruh signifikan dari variabel independen $(X)$ berdampak terhadap variabel terikat $(\mathrm{Y})$ secara sendirisendiri. Hasil pengujian hipotesis secara parsial dapat dilihat dari tabel dibawah ini:

\section{Pengujian Hipotesis}

Tabel 10. Uji Hipotesis Secara Parsial (Uji t) Coefficients $^{\mathrm{a}}$

\begin{tabular}{|c|c|c|c|c|c|}
\hline \multirow[b]{2}{*}{ Model } & \multicolumn{2}{|c|}{ Unstd. Coefficients } & \multirow{2}{*}{\begin{tabular}{|l} 
Std. \\
Coefficients \\
Beta \\
\end{tabular}} & \multirow[b]{2}{*}{$\mathrm{t}$} & \multirow[b]{2}{*}{ Sig. } \\
\hline & $B$ & Std. Error & & & \\
\hline 1 (Constant) & 2.691 & 1.538 & & 1.750 & .141 \\
\hline ZIS & $-4.227 \mathrm{E}-12$ & .000 & -.308 & -2.537 & .052 \\
\hline GDP & 295 & .183 & .156 & 1.607 & .169 \\
\hline Pengangguran & 1.257 & .278 & .638 & 4.526 & .006 \\
\hline Inflasi & -.030 & .044 & -.057 & -.687 & .523 \\
\hline
\end{tabular}

Sumber : SPSS 16, data diolah, 2021

Berdasarkan perhitungan Uji t pada tabel 10. diatas, dapat diketahui bahwa:

1. Hipotesis 1 memperlihatkan pengaruh variabel Zakat, Infaq dan Shadaqah (ZIS) terhadap tingkat kemiskinan dengan nilai signifikansi $0,052>0,05$ dan nilai $t_{\text {hitung }}$ $2.537<\mathrm{t}$ tabel 2.262, sehingga dapat diambil kesimpulan bahwa $\mathrm{H}_{0}$ diterima dan $\mathrm{H}_{1}$ atau hipotesis pertama ditolak yang artinya tidak ada pengaruh antara ZIS $\left(\mathrm{X}_{1}\right)$ terhadap Tingkat Kemiskinan (Y).

2. Hipotesis 2 memperlihatkan pengaruh variabel pertumbuhan ekonomi terhadap tingkat kemiskinan dengan nilai signifikansi 0,169>0,05 dan nilai $\mathrm{t}$ hitung $1.607<\mathrm{t}$ tabel 2.262, sehingga dapat diambil kesimpulan bahwa $\mathrm{H}_{0}$ diterima dan $\mathrm{H}_{2}$ atau hipotesis kedua ditolak yang artinya tidak ada pengaruh antara
Pertumbuhan Ekonomi $\left(\mathrm{X}_{2}\right)$ terhadap Tingkat Kemiskinan (Y).

3. Hipotesis 3 memperlihatkan pengaruh variabel pengangguran terhadap tingkat kemiskinan dengan nilai signifikansi 0,006 $<0,05$ dan nilai $\mathrm{t}_{\text {hitung }} 4.526>\mathrm{t}_{\text {tabel }} 2.262$, sehingga dapat disimpulkan bahwa $\mathrm{H}_{0}$ ditolak dan $\mathrm{H}_{3}$ atau hipotesis ketiga diterima yang artinya ada pengaruh antara Pengangguran $\left(X_{3}\right)$ terhadap Tingkat Kemiskinan $(\mathrm{Y})$.

4. Hipotesisi 4 memperlihatkan pengaruh variabel inflasi terhadap tingkat kemiskinan dengan nilai signifikansi 0,523 $>0,05$ dan nilai $t_{\text {hitung }}-0.687<\mathrm{t}_{\text {tabel }} 2.262$, sehingga dapat disimpulkan bahwa $\mathrm{H}_{0}$ diterima dan $\mathrm{H}_{4}$ atau hipotesis keempat ditolak yang artinya tidak ada pengaruh antara Inflasi $\left(\mathrm{X}_{4}\right)$ terhadap Tingkat Kemiskinan (Y). 


\section{Uji F (simultan)}

Dalam suatu penelitian, uji (F) simultan memiliki tujuan untuk menguji ada atau tidaknya pengaruh dari seluruh variabel independen secara bersama-sama terhadap variabel dependen. Hasil pengujian Uji $F$ yaitu:

Tabel 11. Uji Hipotesis Secara Simultan (Uji F)

\begin{tabular}{|c|c|c|c|c|c|c|}
\hline \multicolumn{2}{|c|}{ Model } & Sum of Squares & $d f$ & Mean Square & $\mathrm{F}$ & Sig. \\
\hline 1 & Regression & 12.039 & 4 & 3.010 & 50.758 & $.000^{\mathrm{a}}$ \\
\hline & Residual & .296 & 5 & .059 & & \\
\hline & Total & 12.336 & 9 & & & \\
\hline
\end{tabular}

Sumber : SPSS 16, data diolah peneliti, 2021

Hasil Uji $\mathrm{F}$ dapat dilihat dari tabel 11. diatas, menujukkan nilai $F$ hitung sebesar $50.758>F_{\text {tabel }} 5.192$ dengan nilai signifikansi (Sig) hasil penelitian sebesar 0,000 $<0,05$ maka berarti $\mathrm{HO}$ ditolak dan Ha diterima sehingga dapat ditarik kesimpulan bahwa tingkat kemiskinan sebagai variabel dependen dipengaruhi secara simultan oleh variariabel independen.

\section{Pengaruh ZIS terhadap Tingkat Kemiskinan}

Dari hasil pengujian maka dikatakan bahwa ZIS $\left(X_{1}\right)$ tidak berpengaruh secara signifikan terhadap tingkat kemiskinan (Y). Nilai $t$ hitung sebesar -2.537 terletak diarea pengaruh negatif. Dengan maka dapat diartikan apabila terjadi peningkatan maupun penurunan ZIS tidak akan mempengaruhi tingkat kemiskinan secara parsial tetapi ZIS berarah negatif terhadap tingkat kemiskinan. Mendukung penelitian yang dilakukan oleh (Mustika, 2019) yang menyatakan bahwa ZIS dan inflasi tidak memiliki pengaruh yang signifikan terhadap tingkat kemiskinan. Dana ZIS yang didistribusikan oleh lembaga zakat tidak efektif dalam mengurangi tingkat kemiskinan di Indonesia.

Minimnya pendistribusian dana ZIS yang di himpun oleh lembaga amil zakat tidak sebanding dengan kebutuhan pokok masyarakat sehingga dana ZIS yang

didistribusikan oleh lembaga zakat tidak efektif dalam mengurangi tingkat kemiskinan di Indonesia. Rendahnya pengaruh ZIS disebabkan oleh peran lembaga zakat belum mampu menghimpun dan mendistribusikan zakat secara tepat dan cepat, minimnya kepercayaan masyarakat terhadap lembaga amil zakat, dan rendahnya informasi yang diberikan kepada masyarakat mengenai kewajiban tatacara dan pedoman pembayaran zakat sebagai implikasi dari kurangnya sosialisasi. (Purbasari et al., 2020).

\section{Pengaruh Pertumbuhan Ekonomi terhadap Tingkat Kemiskinan}

Dari hasil pengujian maka dikatakan bahwa pertumbuhan ekonomi $\left(\mathrm{X}_{2}\right)$ tidak berpengaruh yang signifikan terhadap tingkat kemiskinan ( $\mathrm{Y}$ ). Mendukung penelitian yang dilakukan oleh (Nainggolan, 2020) menyatakan pertumbuhan ekonomi tidak memiliki pengaruh yang signifikan terhadap tingkat kemiskinan di provinsi Sumatera Utara. Hal ini didukung dengan data tingkat kemiskinan dan pertumbuhan ekonomi di Sumatera Utara, terjadinya inkonsisten dalam kedua korelasi. Terdapat tahun dimana meningkatnya pertumbuhan ekonomi, namun tingkat kemiskinan mengalami penurunan, sementara terdapat juga keadaan dimana ketika pertumbuhan ekonomi turun 
tetapi tingkat kemiskinan juga ikut turun. Penelitian yang lain dilakukan oleh (Lubis, 2017) juga menyatakan bahwa pertumbuhan ekonomi tidak memengaruhi tingkat kemiskinan secara signifikan.

\section{Pengaruh Pengangguran terhadap Tingkat Kemiskinan}

Dari hasil pengujian maka dikatakan bahwa pengangguran $\left(X_{3}\right)$ berpengaruh signifikan terhadap tingkat kemiskinan ( $Y$ ). Nilai t hitung sebesar 4.526 terletak diarea pengaruh positif dengan demikian dapat diartikan pengangguran memiliki pengaruh positif terhadap tingkat kemiskinan. Mendukung penelitian yang dilakukan oleh (Khamilah, 2017) yang menyatakan pengaruh positif dan signifikan dari variabel pengangguran terhadap tingkat kemiskinan. Maka artinya setiap meningkatnya pengangguran berdampak pada tingkat kemiskinan yang akan mengalami kenaikan. Pengangguran terjadi karena peningkatan orang yang baru masuk keangkatan kerja dan kemudian mencari pekerjaan tetapi belum memperoleh kerja atau orang yang belum memiliki pekerjaan tetap. Sehingga adanya ketimbangan antara pendistribusian dan ketidakmerataan pendpatan yang menyebabkan kemiskinan. (Alifia, 2020).

\section{Pengaruh Inflasi terhadap Tingkat Kemiskinan}

Dari hasil pengujian maka dikatakan bahwa inflasi $\left(\mathrm{X}_{4}\right)$ tidak berpengaruh signifikan terhadap tingkat kemiskinan ( $\mathrm{Y}$ ). Mendukung penelitian yang dilakukan oleh (Islamiyati \& Hany, 2020) dan penelitian (Fahjarini \& Fahraty, 2020) dengan hasil yang sama mengungkapkan bahwa inflasi tidak mempengaruhi tingkat kemiskinan. Inflasi merupakan indikator ekonomi makro yang menjadi prioritas setiap negara. Maka dari itu, pemerintah melakukan berbagai upaya untuk mengendalikan inflasi agar stabilitas harga tetap terjaga. Meningkatnya pertumbuhan ekonomi biasanya digambarkan dengan kenaikan tingkat inflasi. Penetapan tingkat inflasi yang tepat dan efektif menjadi dasar acuan pemerintah dalam mengurangi kemiskinan yang ada di Indonesia. (Samputra \& Munandar, 2019)

\section{KESIMPULAN}

Kesimpulan yang dipaparkan berdasarkan hasil penelitian dan pembahasan maka secara parsial variabel ZIS, pertumbuhan ekonomi dan inflasi tidak memilik pengaruh secara signifikan terhadap tingkat kemiskinan. Maka apabila terjadi peningkatan atau penurunan nilai dari ZIS, pertumbuhan ekonomi dan inflasi tidak berpengaruh terhadap tinggi rendahnya tingkat kemiskinan. Sedangkan variabel pengangguran secara parsial memiliki pengaruh positif dan signifikan terhadap tingkat kemiskinan, artinya jika terjadi peningkatan atau penurunan pada tingkat pengangguran maka akan berpengaruh searah terhadap tingkat kemiskinan. Seluruh variabel independen yaitu ZIS, pertumbuhan ekonomi, pengangguran dan inflasi secara simultan berpengaruh terhadap variabel dependen yaitu tingkat kemiskinan. Variabel yang paling dominan mempengaruhi kemiskinan di Indonesia tahun 2010-2019 adalah variabel pengangguran dikarenakan memiliki nilai yang lebih besar daripada variabel independen lainnya dan juga memiliki nilai probabilitas terkecil.

\section{SARAN}

Berdasarkan kesimpulan yang telah disampaikan, maka penulis mencoba dapat mengemukakan beberapa saran, yaitu (1) bagi pemerintah pusat maupun daerah memiliki komitmen untuk bekerja sama dengan lembaga amil zakat untuk dapat mengoptimalkan penghimpunan maupun penyaluran dana zakat kepada masyarakat tidak mampu sehingga memiliki tambahan pendapatan dan mengurangi kemiskinan. (2) Pemerintah pusat yang membuat kebijakan fiskal diharapkan untuk lebih fokus dan konsisten dalam upaya untuk mengetaskan kemiskinan dan pemerataan ekonomi agar tidak terjadi ketimpangan. (3) Bagi masyarakat diharapkan dapat bekerjasama untuk mendukung pemerintah dalam program dan kebijakan yang telah ditetapkan 
dalam membangun perekonomian dan menganggulangi masalah kemiskinan. (4) Bagi peneliti selajutnya, disarankan pada penelitian selanjutnya menambah pengujian sampel dengan jangka waktu yang lebih lama dan terbaru agar dapat mengembangkan hasil penelitian yang nantinya menjadikan informasi bagi masyarakat.

\section{DAFTAR PUSTAKA}

Alifia, A. R. N. (2020). Pengaruh zakat, infak, sedekah (zis), pengangguran, dan pertumbuhan ekonomi terhadap kemiskinan di indonesia tahun 2003 2018. Jurnal Ilmiah.

Fahjarini, E. D. N., \& Fahraty, E. (2020). Pengaruh Pertumbuhan Ekonomi, Jumlah Penduduk, dan Inflasi terhadap Kemiskinan di Kota Banjarmasin Tahun 2007-2018. Jurnal Ilmu Ekonomi Dan Pembangunan, Vol. 3 No., 327-341.

Islamiyati, D., \& Hany, I. H. (2020). Pengaruh ZIS dan Faktor Makro Ekonomi Terhadap Tingkat Kemiskinan di Indonesia. Jurnal Ekonomi, 25(1), 118. https://doi.org/10.24912/je.v25i1.631

Khamilah, H. (2017). Pengaruh Pengeluaran Pemerintah, Pengangguran dan Pertumbuhan Ekonomi terhadap Tingkat Kemiskinan di Provinsi Kalimantan Selatan. Journal of Chemical Information and Modeling, 53(9), 16891699.

Lubis, D. S. (2017). Analisis Pengaruh Inflasi Dan Pertumbuhan Ekonomi Terhadap Kemiskinan di Indonesia. At-Tijaroh: Jurnal IImu Manajemen Dan Bisnis Islam, 3(2), 180. https://doi.org/10.24952/tijaroh.v3i2.13 56

Mustika, F. N. (2019). Analisis Pengaruh Zis ( Zakat, Infaq, Dan Upah Minimum Regional Dan Inflasi Terhadap Tingkat Kemiskinan Di Indonesia.

Nainggolan, E. (2020). Analisis Pengaruh Pertumbuhan Ekonomi Terhadap Tingkat Kemiskinan Di Provinsi Sumatera Utara (2010-2019). Jurnal Manajemen Bisnis Eka Prasetya
(JMBEP), Vol. 6, No, 89-99.

Nurotul, fitriyani. (2020). Analisis Pengaruh Dana Zis (Zakat, Infaq, Shadaqah), Tenaga Kerja Dan Indeks Pembangunan Manusia (Ipm) Terhadap Pertumbuhan Ekonomi Di Pulau Jawa Tahun 20122018. INSTITUT AGAMA ISLAM NEGERI SALATIGA.

Purbasari, L. T., Sukmana, R., \& Ratnasari, R. T. (2020). Efektivitas Zakat, Infaq Dan Shodaqoh Dalam Mengentaskan Kemiskinan Di Indonesia: Menggunakan Teknik Basic Needs Deficiency Index. Jurnal Ekonomi Syariah Teori Dan Terapan, $\quad 7(2), \quad 222$. https://doi.org/10.20473/vol7iss20202p p222-233

Samputra, P. L., \& Munandar, A. I. (2019). Korupsi, Indikator Makro Ekonomi, dan IPM terhadap Tingkat Kemiskinan di Indonesia. Jurnal Ekonomi Kuantitatif Terapan, 12(1), 35-46. https://doi.org/10.24843/jekt.2019.v12. i01.p04

Sujarweni, W. (2016). Kupas Tuntas Penelitian Akuntansi Dengan SPSS (Mona (ed.)). Pustaka Baru Press. 